\title{
Negotiations with Terrorist Organizations for the Release of Abductees: Between Declarations and Practice. The Israeli Case
}

\begin{abstract}
For decades, democratic countries have dealt with terrorist attacks carried out for the purpose of negotiations, which is the preferred modus operandi for some terrorist organizations. To what extent can a democratic regime effectively combat this abominable act while preserving a liberal or democratic character? Furthermore, these cases have become one of the most complicated dilemmas in both domestic and foreign policy. The prevalent opinion is that it is not possible to avoid meeting some of the demands of these terrorists. A government may even consent to paying a heavy price, so as to end the situation sooner. Media coverage influences this price, as extensive coverage of the terrorist attacks benefits the terrorists and thus increases their bargaining power. In contrast to the declarations of Israeli leaders in negotiations in cases of abduction, Israel has adopted a very flexible approach and is not interested in adopting the rigid approach of refusal to negotiate. The position of the opponents to negotiations with terrorist organizations is that the very negotiations with terrorist organizations legitimize them and the terrorist attacks, thus devaluing claims that terrorism is not a legitimate means of achieving one's aims, and prevents the use of force in these situations. When all the prisoner exchange deals by the State of Israel are examined, approximately 7,500 terrorists have been released in the framework of the different deals, including terrorists with blood on their hands, in return for 14 living soldiers and civilians and 6 bodies of soldiers. A total of 1,027 terrorists were released in the Shalit deal alone.
\end{abstract}

Key words: negotiations with terrorist organizations, fighting terrorism, national security, democracy, media, Gilad Shalit

\section{Abduction Incidents - Themes}

$\mathbf{F}$ or many years, many thinkers and researchers have addressed the dilemma faced by democratic regimes, including the State of Israel, which seek to preserve their stability while dealing with the challenges of terrorism and political violence. It should be noted that, at the center of the dilemma, there is a crucial question of to what extent such a regime can wage war effectively while maintaining a liberal or democratic character. Or, in other words, can it avoid compromising its own core democratic values to the point where it is little different from the terrorists that it is fighting?

For decades, the democratic states, including Israel, have coped with various bargaining terrorist attacks, which is the preferred modus operandi for many terrorists. In some cases, the countries, including Israel, decided to take action and used military operations to release the hostages, while in other cases they decided upon a strategy of negotiations that, in the end, led to deals that exchanged the abductees for prisoners.

It should be emphasized that abductee release deals became rather significant events in the historical mosaic of the State of Israel throughout its 69 years of independence and even beforehand, when soldiers and/or civilians were kidnapped and, in return for the re- 
lease of these hostages, Israel released prisoners. In addition, these cases became one of the most complicated dilemmas of domestic policy on the one hand and of foreign policy on the other. It is clear that the terrorist organizations benefit from bargaining attacks because of the extensive media coverage, and because of the prestige that the terrorist leaders achieve when the governments submit to their demands. In addition, there is an increase in awareness of the interests that the terrorist organizations seek to promote when countries are forced to undertake disproportional action (Enders, Sandler, 2006).

More than once has the media been accused of serving the terrorists' interests. Walter Laquer explained that, if terrorism is propaganda through action, then the success of the terrorist system depends decisively on the amount of publicity that it receives. The terrorist act itself is nothing; the publicity is everything (Lacquer, 1976, 1977, 1987; see also Schmid, 1992).

Terrorist attacks involving abduction and bargaining have many variables. The identity of the hostages, public opinion, the ability of the abductors and the red lines drawn in the negotiations, and so on, vary from case to case (Faure, 2003).

It is important to note that the terrorist organization's choice of the method of carrying out a bargaining terrorist attack is a very important factor in the success of the attack (Sandler, Scott, 1987; Brandt, Sandler, 2008). This fact strengthens the understanding of the terrorist organizations, whose behavior is in most cases depends on the level of risk (Enders, Sandler, 2006).

Despite the risk, the prevalent position in the literature is that it is not possible to avoid giving something to the terrorists. Researchers presenting this position are aware of the dilemma. On the one hand, giving in to the terrorists in a bargaining attack can encourage additional similar attacks in the future. On the other hand, if the government adopts a policy of not giving in, then the event can end with the murder of the hostages and the responsibility, albeit indirectly, will be placed with the government (Hayes, 2002; Faure, 2003; Sandler, Scott, 1987; Enders, Sandler, 2006).

Regarding methods of dealing with terrorist attacks and abductions, literature that addresses the field of responses to terrorism differentiates between two main models - the 'war model' and the 'justice system model' (Crelinsten, 1987).

The 'war model' will assign responsibility for responding to terrorism to the military, which will make use of all the means at its disposal to deal with the terrorists. The 'justice system model,' which sees terrorism as a crime, will give responsibility for dealing with the situation to the police, who must restrict their activity to within the legal boundaries of the state. In the case of the State of Israel, which fights against radical Islamic terrorism, the relevant model is the war model, but this model, too, is restricted, since, throughout the years of the conflict between Israel and terrorist organizations, when we come to an event in which citizens/soldiers are abducted and held in captivity, negotiations have been used as one of the main tools in the attempts to resolve the crisis (Crelinsten, Schmid, 1992).

In this article, an attempt will be made to provide a concise review of the past three decades of negotiations by the State of Israel with terrorist organizations, and the release of the abductees in three cases. In addition, an attempt will be made to describe the changes that have occurred throughout the past three decades, and how this was reflected in negotiations for the release of the soldier Gilad Shalit from the captivity of Hamas. 
The changes that occurred as a direct result of this will have direct influence on the manner of negotiations that result from this type of crisis in the future.

\section{The 'Price' as a Factor Influencing the Decision to Negotiate}

The main factor that influences the price and the concessions made is changes in the costs of the negotiations. According to the formal model, these changes influence both the terrorists' demands and the government's demands, and may influence the degree of concessions. These changes will also influence the question in principle of whether to make concessions at all. The increase in the cost of the bargaining will also influence the duration of the terrorist attack (Atkinson, Sandler, Tschirhart, 1987). One example is that, in barricade terrorist attacks, and possibly also in abduction terrorist attacks, the abductors can kill hostages while setting deadlines. This situation definitively increases costs to the government holding negotiations. Therefore, the government may increase the level of concessions and agree to a heavy price, so as to quickly end the situation. If from the beginning the government knows the cost of submission to the terrorists, then the government will consider whether or not to enter into negotiations. Namely, if the cost of submission is greater than non-submission, then there will be no deal. Into the cost of submission it is necessary to include the identity of the hostages. For instance, in the event in Maalot, children were taken hostage, and this fact increased the cost (Enders, Sandler, 2006).

Another factor that influences the cost is media coverage. The prevalent opinion in literature is that increased media coverage benefits the terrorist organizations, and their bargaining power increases. Dolnik (2003) maintains that the media focusing on the abductees and their families may have a negative impact and may increase the terrorists' demands. Faure (2003) holds that the intervention of third party factors, such as the media and the hostages' families, influences the final outcomes of the event.

It should be noted that after the Jibril agreement, there was a series of deals in which Israel obtained bodies. In essence, all the deals that came afterwards included the return of bodies, with the exception of the Tannenbaum deal, in which both bodies and a living abductee were returned. Therefore, it is hard to measure the influence of the Jibril agreement, since the previous deals were of the type of 'a life for a life.' It seems that the release of bodies, as opposed to the release of living prisoners, is perceived by the decision makers and the public to be easier.

Negotiating for the release of hostages in a bargaining terrorist attack is a complex process and every negotiation has its own particularities and complexities, and therefore, from a practical perspective, it is not possible to provide one strategy for negotiations. It is necessary to add that research literature addressing the topic, which must adjust to each and every case in the negotiations and in the measurement of the bargaining ability of states, is sparse (Dolnik, 2003). Nevertheless, the impression is that, in the light of data and analysis, the bargaining ability of Israel has deteriorated over the years in this type of negotiation and that this fact influences the price that is set. It is possible to see a decline in bargaining ability in a number of sub-categories. It should be remembered that, according to literature, concessions to the terrorist organizations in negotiations 
will lead to additional concessions. The issue which connects the mentioned cases is that Israel, in its approach in most abduction terrorist attacks, was immediately interested in entering into negotiations. In other words, the appeal to the Red Cross and to other international actors, as well as to the terrorist organizations themselves, through the private mediators, was more or less immediate in all the deals. Namely, in all that pertains to the entry into negotiations in cases of abduction, Israel adopted a completely flexible approach and was not interested in adopting the rigid approach of refusal to negotiate. To measure the bargaining ability of Israel in this subcategory, it is necessary to analyze the behavior of the terrorist organizations and to examine the length of time that they waited before entering into negotiations, and the conditions that they set as a requirement for this. According to this theory, as the sovereign state was forced to wait a longer time, despite its position, the bargaining power of the terrorist organization increased.

The release of living terrorists has serious implications - the terrorist may return to terrorism, and it is possible that their release will incentivize other terrorists to undertake terrorist attacks, since they know that they can expect to be released in a future deal. There is also harm to the legal principle of the punishment of terrorists for their actions and the failure to serve their sentences because of a political decision, and not for accepted legal reasons. Therefore, the handing over of bodies is perceived as less serious.

Another tendency identified in literature is that governments will more often reject the demands to release prisoners than other demands, such as ransom, publicity, and so on. Namely, the release of prisoners is considered a heavy price and therefore governments will try to avoid paying it (Enders, Sandler, 2006; Faure, 2003; Hayes, 2002; Sandler, Scott, 1987).

Terrorist organizations will carry out terrorist attacks according to the experience they have accumulated and according to the means of defense adopted by the governments. Thus, for example, it was proven that the hijacking of planes decreased significantly after the installation of security facilities in airports, and consequently the attacks on the embassies increased. When the security for the embassies was reinforced, this type of event decreased (Hayes, 2002). In Iraq, after the invasion by the United States and its allies in 2003, many citizens and soldiers were kidnapped. Enders and Sandler (2006) found that the release of hostages in exchange for concessions from their country quickly led to the capture of new hostages. Thus, they assert that only if the governments do not meet the abductors' demands or take punitive measures against the terrorists will the number of abductions decrease (Enders, Sandler, 2006).

\section{Negotiations with Terrorism: the Policy of Announcements versus Action}

The State of Israel's sensitivity to and sense of responsibility for the lives of its soldiers and citizens who are captives of its enemies, which is anchored in Jewish tradition, are unusual compared to what exists in other democratic states around the world. Thus, all deals to release abductees and captives, also called the redemption of captives, which were agreed between Israel and its enemies, raise the following question: is sensitivity to the lives of the country's citizens and soldiers an expression of power and mutually guaranteed protection or does it reflect the weakness of Israel and its inability to determine a solution 
that is not the release of terrorists in return for its abductees? This weakness is exploited by the enemies of Israel in order to obtain far-reaching concessions (Shwitzer, 2008).

Those who argue against negotiations with terrorist organizations base their claims on the observation that the very fact of negotiating with terrorist organizations legitimizes the organization and terrorist activity in general. Therefore, it devalues the government's claims that it does not support terrorism and precludes a response involving force (Neumann, 2007).

In order to focus on the subject of negotiations with terrorist organizations in more detail, the definition of terrorism will include two sub-definitions - violence and a political goal. The logic behind narrowing down the definition is that the abduction of citizens and/or soldiers for the purpose of bargaining is intended to cause demoralization, hence, to achieve a political goal. It should be noted that the abductors from terrorist organizations do not treat the abducted soldiers as war captives according to the Geneva Convention, and therefore this strengthens the understanding that the abduction of soldiers is intended for purely political and not military objectives. Different terrorist factions can perform abductions and their actions can be classified as terrorist events as they are nonstate actors; otherwise they would be classified as war crimes (Ganor, 2003).

Bargaining-and-abduction terrorist attacks are affected by many variables, including the identity of the hostage, public opinion, the motives and ability of the abductors, red lines drawn in the negotiations, and so on (Faure, 2003).

A number of studies have indicated that, as governments make more concessions to terrorist organizations and meet their demands, the terrorist organizations increase their violent activity and attempts to abduct people. Since abduction events raise the prestige of the terrorist organization, due to the extensive media coverage they receive (Enders, Sandler, 2006), the policies regarding negotiations with terrorists of countries that experienced abduction and terrorism were examined, and it was found that, in countries that systematically conceded, there was a threefold increase in terrorist incidents. By contrast, states that actively took steps to combat terrorism saw a significant decrease in the number of terrorist attacks against their country (Hayes, 2002).

Another interesting theoretical model is the model of Islam and Shahin (1989). According to this model, the behavior of governments in the past in the management of negotiations shed light directly on, and may influence, the taking of hostages in the future (Islam, Shahin, 1989).

Concessions lead terrorists to the conclusion that concessions in the future will increase. There are cases in which concessions will be very influential, and there are other situations in which concessions have less influence (Brandt, Sandler, 2009; Lapan, Sandler, 1988).

There are two main approaches to negotiations with terrorist organizations; the 'flexible' and the 'rigid' approach. According to the flexible approach, it is necessary to conduct negotiations with terrorist organizations, but within certain limits. In contrast, the rigid approach maintains that negotiations should not be conducted with terrorist organizations in any event and prisoners who have been convicted and sentenced should not be released, even in return for hostages (Ganor, 2001).

Negotiating for the release of hostages is a very complex process and every event has its own particularities and complexities. Therefore, in practical terms it is not possible to use one strategy for negotiations in every case (Dolnik, 2003). 
The complexity of negotiations with a terrorist organizations and the difficulty in achieving a successful end, even when much has been agreed upon, can lead to a situation in which, after the sides reach an agreement, the decisions will not be implemented (Faure, 2003).

Another factor that influences the decision to negotiate or not with terrorist organizations is the media coverage that accompanies the event. Increased coverage of terrorist events makes them more profitable to terrorist organizations, and may even increase their bargaining demands. Dolnik (2003) maintains that the focus of the media on the abductees and their families may have a negative impact and increase the terrorists' demands. In addition, Faure (2003) holds that the intervention of third parties, such as the families of the abductees or the media, influences the final outcome of the event.

The main dilemma facing the decision maker is balancing the need to release the hostages without submitting to the terrorists' demands, or causing the hostages' death, without appearing weak or irresponsible as a government. This dilemma is exacerbated by time pressure, media pressure, and public opinion (Herman, Charles, 1998).

There is a reason why terrorists choose bargaining-and-abduction attacks. Terrorist organizations know that the country that is attacked and blackmailed is not able to exert its full force in such an event and, therefore, it has no advantage. Therefore, this kind of attack is preferable (Crenshaw, 1998).

The approach of the Prime Minister of Israel, Binyamin Netanyahu, to the release of incarcerated terrorists is commensurate with the 'rigid approach' in the counter-terrorism field. Netanyahu emphasized in his books the need not to submit to terrorists' demands and to avoid the release of imprisoned terrorists in return for hostages. Netanyahu defined the bargaining terrorist attack as a 'classic terrorist action' (Netanyahu, 1987).

The Prime Minister of Israel is not alone in adopting the rigid approach. The United States is one of the most prominent countries that have adopted the rigid approach to bargaining attacks and abductions. Its policy is based on three 'noes:' no to negotiation with terrorists, no to concessions, and no to ransom. This policy has been strongly criticized by experts, who assert that the policy is a death sentence for American hostages (Hudson, 1989).

However, most of the presidents of the United States in the $20^{\text {th }}$ century did not succeed in effectively implementing the principles of the rigid policy in terrorist blackmailing attacks. In the case of the terrorists from the Black September organization that took over the Saudi embassy in Khartoum during a reception for an American diplomat in 1973, President Nixon announced that he was not willing to submit to blackmail and the abductors murdered the hostages. The Reagan government also announced the adoption of a rigid policy regarding hostage crises and even declared that there would be no release or concession in the case of abduction, which he considered submission to terrorists, and that no ransom would be paid or prisoners released, so as not to encourage terrorism. However, when the Reagan government was forced to deal with the hijacking of a TWA flight, with 122 American citizens aboard, to Beirut, Lebanon, in June 1985, the American government, under President Reagan, acted to pressure Israel into releasing terrorists it held in Israeli prisons (Jones, 2005).

Regarding the State of Israel, when abductions over the years are reviewed, it is possible to see that the declared policy was to convey rigidity, while its actual approach 
in most abduction terrorist attacks was to enter into negotiations immediately. In other words, the appeal to the Red Cross and to other international actors, as well as to the terrorist organizations themselves through private mediators, was almost immediate in all the deals. In all that pertains to the entry into negotiations in cases of abduction, Israel adopted a completely flexible approach and was not interested in adopting the rigid approach of refusing to negotiate.

In the three cases that will be described in this article - the Jibril agreement, the Tannenbaum agreement and the Gilat Shalit agreement - it is clear that the State of Israel sought to conduct negotiations as quickly as possible so as to end the abduction event in a short period of time, in contrast to its declared position that negotiations with terrorists should not be conducted.

\section{Events leading to the Release of Captives}

This part of the article will describe three cases of abduction/captivity. Every case will be described with reference to the organization that performed the attack and the State of Israel's response, and, in addition, other relevant events that took place during the negotiations will be described.

\section{The Jibril Agreement}

On June 10, 1982, several days after the beginning of the First Lebanon War, a brigade of tanks entered a bloody battle in the Sultan Yacoub village in Lebanon. A number of soldiers were captured, and a few are still missing to this day. In the midst of the fighting, another soldier was captured, but the State of Israel did not realize that he was captured by a terrorist organization for a long time (Ben Porat, 1985). Three months afterwards, Palestinian terrorists from the PLO attacked an IDF observation position in the Bhamdoun Village in Lebanon and captured eight IDF soldiers (Amikam, 1982). Six of the captives were given to the PLO and two to Ahmed Jibril's organization. The soldiers were separated, apparently, because of lack of space in the vehicle that transported the soldiers (News Agency, 1983).

At the time of the abductions, a right-wing government under Prime Minister Menachem Begin was in office, but, after a while, this government was replaced by a unity government in which Yizchak Shamir and Shimon Peres served as Prime Ministers in rotation. Yizchak Rabin served as the Defense Minister, and the person who managed the agreement was the lawyer Shmuel Tamir. Until the implementation of the PLO agreement (November 1983), Israel insisted on negotiating for all eight soldiers (Haver, 1983). However, Ahmed Jibril's organization was very difficult in the negotiations (Haver, 1983). In August 1983, Yasser Arafat, the PLO leader, announced that he could not enforce his authority over Ahmed Jibril's organization and therefore he would discuss only the six soldiers that he had (Ben Porat, 1985).

The decision by Israel to divide the negotiations occurred in October 1983, after the six soldiers were brought to the city of Tripoli in Lebanon, where their lives were endan- 
gered because of riots that broke out in the city (Amikam, 1984). The Jibril abductees were held by the organization in Damascus. On October 13, 1983, the negotiations with the PLO commenced.

Jibril's original demand was the release of 1,187 terrorists from Israeli prisons (Shavit, 1985). Around July 1984, significant negotiations with Jibril commenced. Two months later proximity talks began in which Israel was willing to release only 25 terrorists. The Israeli delegation announced the cessation of the negotiations and returned to Israel. In October 1984, Jibril informed Bruno Kreisky that the negotiations had failed since Israel used the fact that they had captured Jibril's nephew. In January 1985, a proposal was discussed in the office of Defense Minister Rabin, but the manager of the negotiations, Shmuel Tamir, objected to it. Rabin approved the continuation of contact. Jibril decided to refuse the proposal but accepted it as the basis for negotiations (Tamir, 2002).

At the end of February 1985, Jibril recanted and said he would not come to Vienna to form the agreement unless Israel agreed to release all 1,187 terrorists, as he had demanded from the beginning. After a turbulent meeting, the political delegation accepted the proposal in a meeting held in March 1985. Israel was not interested in releasing 36 terrorists from the list. Eventually it was determined that 18 prisoners would not be released, when Jibril insisted that he would determine who would and would not be released (Haver, 1985). On May 21, 1985, the Jibril Agreement was implemented. The three soldiers, Yosef Grof, Nissim Salem and Hezi Shai, were returned to Israel and 1,150 terrorists were freed. In Israel there was a lively public discussion on the question of what 'price' should be paid in such deals.

\section{Release of the Three Soldiers Captured at Mount Dov and Elhanan Tannenbaum}

The negotiations in this agreement began in two separate events. On October 4, 2000, an officer (reserve) in the IDF, Elhanan Tannenbaum, went to Dubai in the Persian Gulf for a drug deal. It became clear that Tannenbaum had incurred heavy debts, primarily because of gambling. A number of Israeli Arabs had convinced him to go to Dubai for this deal. Tannenbaum was abducted by Hezbollah and flown to Lebanon. After a week and a half, Nasrallah, the head of Hezbollah, announced that the organization was holding a reserve IDF colonel captive. The IDF began to examine who in its ranks was missing, and, after a period of time, it was discovered that Tannenbaum was missing. Nasrallah released Tannenbaum's name and then Israel began its attempts to obtain his release (Bergman, 2009).

The second event began on the Sabbath, October 7, 2010. An IDF reconnaissance vehicle went to point 590 on the Lebanese border fence in the Mount Dov region for routine reconnaissance. This point was problematic due to its lack of CCTV coverage. A powerful explosive charge was activated against the patrol. A Hezbollah cell approached the fence, exploded it, and opened it for a car that approached the IDF reconnaissance vehicle. The terrorists forcibly removed three soldiers from the IDF vehicle - Benny Avraham, Adi Avitan, and Omar Sawaid. The Hezbollah vehicle rapidly returned to Lebanese territory and, by the time the military system had been activated, the abductors and the soldiers were already deep in Lebanon, in an unknown location (Shifer, 2000). 
A day after the abduction of the soldiers at Mount Dov, Israel began negotiations under the leadership of Yakov Perry (Perry, 2000). The initial goal was to obtain a sign that the soldiers were alive. Hezbollah said that they would release the abducted soldiers only in return for Lebanese prisoners, and would not release information about their fate without anything in return. A number of days after the abduction, Hezbollah announced that it was willing for the United Nations to mediate. After it was discovered that Tannenbaum had been abducted (October 15, 2000), Israel turned to the Red Cross and the United Nations (Shibi, 2000).

In December 2000, contact in preparation for the deal began. Israel wanted information on the fate of the soldiers, without announcing what it was ultimately willing to concede. After some time, Israel conveyed to Hezbollah its willingness to release nineteen Lebanese prisoners who were held in Israel, including Mustafa Dirani and Sheik Obeid. One of the reasons for the change was an understanding among decision-makers, according to whom holding Dirani was no longer beneficial for the purpose of the release of the captured navigator Ron Arad. This was a small victory for Nasrallah, who agreed in return to begin the negotiations (Perry, 2000).

Towards the end of August 2003 there was a breakthrough, when Israel gave up on receiving information about Ron Arad (Yechezkeli, 2004).

The German mediators indicated that, faced with Hezbollah's demands, Israel presented rigid demands of its own. In September 2003, Prime Minister Sharon informed the Arad family that it was possible that Dirani and Obeid would be released in the coming exchange (Shifer, 2003).

Nasrallah, on his part, set demands that included the release of Palestinian, Lebanese, Syrian, and Jordanian prisoners. A short time later Israel removed all objections to the release of the Palestinian prisoners. In the beginning of October 2003, there were reports, primarily from the mediator, that Tannenbaum was being tortured in captivity (Shifer, 2003). After receiving this information, Prime Minister Sharon decided to advance the negotiations, fearing for Tannenbaum's life.

Ilan Biran, the manager of the negotiations, met with the mediator and conveyed to him Israel's final proposals, according to which Dirani and Obeid would be released, along with hundreds of Palestinian prisoners and the bodies of dozens of Hezbollah men (Bergman, 2003).

It appears that the main argument in this stage of the negotiations revolved around Dirani. Supporters of Dirani's release claimed that he was no longer a bargaining chip for Ron Arad. Opponents of his release claimed that Ron Arad was a symbol and recommended standing firm on the Dirani issue, at most proposing additional prisoners in his stead (Yarkoni, 2004).

In January 2003, Nasrallah announced for the first time that Tannenbaum was alive (Glickman, 2003). In July 2003, Nasrallah said that Hezbollah was holding three soldiers whose fate was not known, as well as a living civilian (Perry, 2003). In the middle of August, the Foreign Affairs Minister Silvan Shalom said that Hezbollah was interested in the wholesale release of prisoners in return for information only, and this demand was not reasonable. On August 23, 2003, the German mediator visited Tannenbaum, received a letter from him, and stated that he was in a good condition. In return for the visit, Israel returned two bodies of Hezbollah members (Beck, 2003). 
Regarding the soldiers, Hezbollah did not reveal until the very last moment whether the soldiers were dead or alive. The decision of Israel to announce that they were fallen soldiers was based solely on intelligence (Bergman, 2009).

On November 9, 2003, the government of Israel decided, twelve to eleven, that in return for Tannenbaum and the soldiers' bodies, 400 Palestinian prisoners, as well as 21 Lebanese, 5 Syrian, 3 Moroccan, 3 Sudanese, one Libyan, one British and one German prisoner, would be released. In addition, 59 terrorists' bodies and maps of the IDF's mined fields in South Lebanon would be handed over (Eichner, 2003).

After the decision was made, Hezbollah made another demand - the release of the terrorist Samir Kuntar, who was a member of the cell that murdered the Haran family in Nahariya in the late 1970s. Prime Minister Sharon said that his release was a red line, and that he was willing to call off the deal. Nasrallah stated that if Kuntar was not on the list of terrorists to be released, then the deal was off. The negotiations entered a stage of complete secrecy (Eichner, 2003). In the middle of January 2004, Ilan Biran announced that Hezbollah had decided to forego the Kuntar issue (Shifer, 2004).

On January 29, 2004, the prisoner exchange was carried out. Israel released 400 Palestinian prisoners, 36 other prisoners from different countries, and 59 bodies. In return, Elhanan Tannenbaum was released and the bodies of the three soldiers taken at Mount Dov were returned (Yechezkeli, 2004).

\section{The Shalit Prisoner Exchange and the Resultant Change}

On the morning of Sunday June 25, 2006, a Hamas cell attacked a Merkava tank positioned to guard the perimeter fence adjacent to the Gaza Strip and an IDF outpost, both in the territory of Israel, after it crossed the border from the South Gaza Strip through a tunnel towards the Kerem Shalom crossing. During the attack, the tank commander and a soldier in the tank were killed and Gilad Shalit was abducted to the Gaza Strip. An exchange deal signed between Israel and Hamas in October 2011 and mediated by Egypt signaled the end of exhausting and tortuous negotiations that lasted five and a half years.

In May 2011, with the entry of David Meidan, a new coordinator, on behalf of the Prime Minister of Israel, the increasingly close relationship between senior members of the Egyptian security establishment and senior representatives of Hamas after the fall of Hosni Mubarak and the departure of Omer Suleiman, who had been responsible for the Egyptian security services, and the increasing agitation in the Arab world created new constraints on the Hamas leadership and on the Israeli government and spurred both sides to hold several rounds of negotiations in Cairo in August-October 2011. A conclusion to this round of negotiations was made possible following the increase in flexibility by the two sides, including Hamas agreeing to forego its long-standing demand for the release of all the 'heavy' prisoners, and to remove a large number of released prisoners from the West Bank to the Gaza Strip or, in a few cases, abroad (Limor, 2011).

The return of Gilad Shalit to Israel on October 18, 2011, in return for the release of many political prisoners and mainly convicted murderers who had been given life sentences for the murder of Israelis, following the signing of the agreement called the Shalit Deal between the Israeli government and Hamas (Shwitzer, 2011), inspired public 
debate regarding the principles that are always concomitant with this type of negotiation between Israel and terrorist organizations.

The question of the price that Israel paid in the Shalit prisoner exchange has been discussed extensively and publicly. The reason, beyond the heavy price itself, lies in the open nature of the many channels of media coverage and the nature of the public discourse that characterizes modern Israel. The Hamas representatives in the negotiations faced the precedents of previous prisoner exchanges Israel conducted with terrorist organizations that had held its soldiers or citizens captive, when the main model was that which resulted in the Jibril prisoner exchange agreement, the outcome of which was presented as a historical victory for the Palestinian people.

It should be emphasized that Hamas was eventually forced to make significant concessions, which beforehand it had refused to do, and it reluctantly accepted and adhered to the threshold conditions that Israel had set. Therefore, the spokespersons of the Israeli government were able to maintain that, given the conditions that existed at the time, this was the best possible deal (Netanyahu, 2011). The main profit for Hamas was that it succeeded in forcing Israel to concede on a number of principles that the decision-makers had presented during the negotiations as 'red lines,' which in the past the leaders of Israel had declared Israel could never agree to cross (Shwitzer, 2012).

The Shalit prisoner exchange first and foremost gave Hamas an important, prestigious achievement, primarily in terms of Palestinian public opinion, but also beyond this. For the first time in its history, Hamas had held captive a soldier for a prolonged period of time and had thwarted Israel's attempts to discover the place where the soldier was hidden in order to then release him in a military operation.

The deal signed between Israel and Hamas in October 2011 that was mediated by Egypt led to the end of the five and a half years of exhausting and torturous negotiations. Over the years the process had had ups and downs and even a period of disconnection between the sides (Shwitzer, 2012).

The biggest win for Hamas derived from the fact that 1,027 prisoners were released in return for one Israeli soldier. Thus, a precedent was set for the 'price' of one Israeli captive.

There are very many good reasons to object to the Shalit prisoner exchange deal. The deal was, in essence, Israel's surrender to terrorism. The deal would strengthen Hamas, weaken Abu Mazen and Salam Fayyad, and empower extremists in the Arab world and Palestine, increasing the risk that Israeli soldiers would be abducted in the near future or that a new wave of terrorist attacks would sweep over Israel. It would also strengthen the opinion that Israel's sensitivity to the lives of its citizens is its Achilles heel and that Israel is not a real power; the deal to save Gilad Shalit's life may have cost the lives of many other Israelis in the future (Shavit, 2011).

Another aspect that accompanied the implementation of the second stage of the deal and contributed to the image of Hamas as the winner was the shaky relations between the Palestinian Authority and the government of Israel at that time.

Despite these declarations and the aforementioned achievements, the negotiators from Hamas were forced to forego a number of their own principles. The number of prisoners was reduced, and prisoners who were symbols of the struggle were not included in the list of released prisoners. Some of the prisoners were removed from the regions of Judea and Samaria and sent abroad or to Gaza. 
Israel, for five and a half years, paid different prices as a direct result of its failure to mount a military option for the release of the abducted soldier, beyond the projection of submission and weakness. The implications of the event, and the investment of many resources, revealed the limitations of Israeli power in forcing Hamas to release the abducted soldier, including via the exertion of pressure.

The lengthy negotiations and the delay in the finalization of the prisoner exchange deal cost Israel dear and increased the polarization in its internal public discourse that reached its apex with the signing of the agreement.

In 2008, due to the lessons learned from the Shalit deal, a committee was established to address the issue of the release of abducted and missing people. The committee, which was established to draw up a policy for the management of future negotiations for abducted and missing Israelis, under the leadership of the former Supreme Court President, Meir Shamgar, concluded its mission in 2012 and submitted its findings to the Defense Minister, Ehud Barak (Buchbot, 2012).

The main recommendation of the committee was that responsibility for managing the return of captives and abductees should be shifted to the Ministry of Defense and not the Prime Minister, as had been the case in the past. The Ministry of Defense should have a department for handling the captives, maintain contact with their families, and be responsible for conducting negotiations, while keeping the government informed. When agreements with the abducting side are reached, the decision to implement the prisoner exchange should be brought to the government (Buchbot, 2012).

In 2014, a law proposal ${ }^{2}$ was submitted to the Israeli Knesset regarding principles for the redemption of captives and missing people. The Knesset members who initiated the project wanted to implement the conclusions of the Shamgar Committee, although they were not published. The goal of the law proposal was to determine the appropriate principles for deals for the return of captives and missing people, based on the recognition that the release of many terrorists in return for a few soldiers or bodies of soldiers creates an incentive to abduct soldiers for the purpose of bargaining, and brings dangerous terrorists back into the ranks of terrorist organizations. In addition, the principle of deterrent is undermined if potential terrorists understand that their family will receive financial assistance and they will receive praise and be released in a coming prisoner exchange deal should they be captured; the present policy could even be viewed as an incentive for terrorists, as it signals to them that, in the end, they will not serve their sentences.

It should be noted that a law has yet to be passed that creates a framework for balancing all of these factors, both defense and political, in Israel. Israel may find itself in a similar situation at any given moment and will be forced to cope anew with the dilemmas and the difficulties that emerged in the previous deals, especially in the Shalit prisoner exchange deal.

\section{Conclusions}

The State of Israel is known for agreeing to pay heavy prices for its captive soldiers, as well as for the bodies of its fallen soldiers. Prominent examples are the exchange of the Nahal prisoners, in which 4,765 terrorists were released in return for six soldiers, the Jibril 
agreement, in which 1,150 terrorists were exchanged for the return of three soldiers who had been captured, the Shalit deal in which the abducted soldier Gilad Shalit was released in return for 1,027 terrorists, and a prisoner exchange deal with the Hezbollah in which 450 terrorists were returned for the bodies of three IDF soldiers and one living citizen (Elhanan Tannenbaum). All in all, in the framework of the different deals, the State of Israel released about 7,500 terrorists, including convicted terrorists with blood on their hands, in return for fourteen living soldiers and citizens and the bodies of six soldiers.

Israel had an established strategy, albeit unwritten, that was determined in the 1970s by the then Prime Minister, Yizchak Rabin, and it was that, if a military solution was possible, then this option is preferable, but lacking such an option the government will conduct negotiations with the terrorists and will be willing to respond to their demands in return for the release of the hostages. This policy was adopted by the different governments of Israel over the course of many years.

The issue of the deals to return the abductees is one of the most sensitive issues amongst the Israeli public. Public discussion on the topic is highly emotive, when the principles of the return of the captives, national security, the values of the IDF, the need for a deterrent, and so on are combined and, indeed, impossible to separate. Decisionmakers must attempt to find a delicate balance between the immediate need for the release of the hostages and abductees, and the avoidance of actions which will likely cause an escalation of the security situation and endanger the lives of other citizens.

Analysis of these attacks in Israel indicates that terrorist organizations prefer to undertake abduction terrorist attacks following the Israeli military response to barricade terrorist attacks, and due to the rise in cost, which, according to literature, causes the terrorist organizations to again undertake the kind of attack in which they regularly achieve success and increase their demands every time.

Therefore, in the framework of the law proposal on the release of abductees and the concomitant price, the initiators intended that the abduction of an Israeli should be viewed as a terrorist event in all respects. Section 2 of the law stipulates the principles according to which the government needs to act within the framework of the negotiations to sign an exchange deal with a terrorist organization: one terrorist will be released for one soldier; live terrorists will not be released in return for soldiers' bodies, and the terrorist organization will choose the terrorists that it wishes to have released from a closed list that the government will determine. In addition, in the framework of the proposed law, a mechanism will be arranged according to which it is possible to release up to ten additional terrorists before the release of the abducted soldier, if the government believes that this step will promote negotiations with the terrorist organization.

Despite the attempt to legally set the price of negotiations and the number of people to be released, and even an attempt to impose a limit on the release of terrorists on the basis of some criterion relating to the severity of the crimes they have committed - it failed. The Israeli governments were obligated to 'pay' steadily increasing prices, in terms of the number of terrorists released from prisons in Israel, in return for the release of abductees and hostages.

However, the reverse policy of the adoption of a rigid line in all that pertains to the release of imprisoned terrorists did not last long in the countries that adopted it, including Israel, which was compelled to release terrorists. 
Is it possible to deter terrorism from the beginning and thus avert the next abduction attack? Many rule out this possibility, since non-state or semi-state actors lack, for the most part, important resources that can be threatened. The absence of such vulnerable assets constitutes a source of concern for those in charge of the formation of counterterrorism policy.

It is clear to all that, despite Israel's pronouncements on the avoidance of the legitimization, even indirect, of terrorist organizations by negotiating with them, in reality there is intensive communication at the time of the abduction so as to resolve the situation and the resulting crisis. The prolonging of the negotiations and the delay in the conclusion of the deal, especially in the Shalit prisoner exchange deal, cost Israel dear, in that it increased polarization in Israeli public discourse, which reached its apex on the evening of the signing of the agreement with Hamas, and caused doubt, at least amongst some of the Israeli public, regarding the decision-making ability, leadership, and moral authority of the Prime Minister, and even cast doubt on the absolute validity of some fundamental values, such as the mutual guarantee between citizens and the state and the obligation to redeem captives, in modern Israeli society.

\section{Bibliography}

Atkinson S., Sandler T., Tscirhart J. (1987), Terrorism in a Bargaining Framework, "Journal of Law and Economics," vol. 30, pp. 1-21.

Brandt P. T., Sandler T. (2008), Hostage Taking: Understanding Terrorism Event Dynamics, The University of Texas at Dallas.

Crelinsten R. D. (1987), Terrorism and Political Communication: The Relationship between the Controller and the Controlled, in: Contemporary Research on Terrorism, eds. P. Wilkinson, A. M. Stewart, Aberdeen University Press, Aberdeen, pp. 3-23.

Crelinsten R. D. (1989), Terrorism, Counter-Terrorism and Democracy: The Assessment of National Security Threats, "Terrorism and Political Violence," vol. 1, no. 2, pp. 242-269.

Crelinsten R. D., Schmid A. (1992), Western Responses to Terrorism: A Twenty-Five Year Balance Sheet, "Terrorism and Political Violence," vol. 4, no. 4, pp. 332-333.

Crenshaw M. (1998), The Logic of Terrorism: Terrorist Behavior as a Product of Strategic Choice, in: Origins of Terrorism, ed. W. Reich, Woodrow Wilson Center Press, pp. 21-22.

Dolnik A. (2003), Contrasting Dynamics of Crisis Negotiations: Barricade versus Kidnapping Incidents, "International Negotiation," 8, pp. 495-526.

Enders W., Sandler T. (2006), The Political Economy of Terrorism, Cambridge University Press, New York.

Faure G. A. (2003), Negotiating with Terrorists: The Hostage Case, "International Negotiation," 8, pp. 469-494.

Hayes R. E. (2002), Negotiations with Terrorists, in: International Negotiation, ed. V. Kremenyuk, Jossey-Bass, San Francisco.

Hermann M. G., Charles F. (1998), Hostage Taking, the Presidency and Stress, in: Origins of Terrorism, ed. W. Reich, Woodrow Wilson Center Press, pp. 211-212.

Hudson A. R. (1989), Dealing with International Hostage-Taking: Alternatives to Reactive Counterterrorist Assaults, "Terrorism and International Journal," vol. 12, no. 5, pp. 322-323.

Islam M. Q., Shahin W. N. (1989), Economic Methodology Applied to Political Hostage-Taking in light of the Iran-Contra Affair, "Southern Economic Journal," 55(4), p. 1019. 
Jones R. (2005), Terrorist Beheadings: Cultural and Strategic Implications, p. 3.

Lapan H. E., Sandler T. (1988), To Bargain or Not To Bargain: That Is the Question, "The American Economic Review," 78(2), pp. 16-21.

Laqueur W. (1976), The Futility of Terrorism, March. Harper's.

Laqueur W. (1977), Terrorism, Weidenfeld \& Nicholson, London.

Laqueur W. (1987), The Age of Terrorism, Little, Brown \& Co, Boston, MA.

Neumann R. P. (2007), Negotiating with Terrorists, "Foreign Affairs," 86(1), pp. 128-138.

Sandler T., Scott J. L. (1987), Terrorist Success in Hostage-Taking Incidents: An Empirical Study, "The Journal of Conflict Resolution," 31(1), pp. 35-53.

Schmid A. P. (1992), Editors' Perspectives, in: Terrorism and the Media, eds. D. L. Paletz, A. P. Schmid, Sage, Newbury Park, CA, pp. 111-136.

\section{Literature (Hebrew):}

Bergman R. (2009), The State of Israel Will Do All, Kineret and Zmora Beitan.

Ganor B. (2001), Israel's Policy in the Coping with Terrorism: Effectiveness versus Democratic-Liberal Values, Ph.D. Dissertation, The Hebrew University of Jerusalem.

Ganor B. (2003), The Maze of Counter-Terrorism - Tools for Making Decisions, The Herziliya Interdisciplinary Center, Mifalot Press.

Netanyahu B. (ed.) (1987), Terrorism - How The West Can Win, Israel, Sifriat Maariv, p. 233.

Shwitzer Y. (2008), The Release of Captives Deals - War between Just and Conflicting Values, Institute for National Security Researches, A Look from above, 61, July.

Shwitzer Y. (2011), The Exchange Agreement between Israel and Hamas - From Tactical Failure to Strategic Challenge, "A Look from above," 289 (23), October.

Shwitzer Y. (2012), The Sting in the Tail - Achievements and Failures in the Exchange Deal between Hamas and Israel, "Strategic Update," vol. 14, iss. 4, January.

Tamir S. (2002), A Son of This Land - Autobiography, Zmora Beitan.

\section{Press (Hebrew)}

Amikam Y. (1984), Tamir: We Faced a Brutal Choice: Six or None, "Yediot Acharonot," June 29, p. 5.

Amikam Y., Zimoki A. (1982), Israel Warns the Syrians: Demands Release of 8 Kidnapped Soldiers, "Yediot Acharonot," September 9, p. 1.

Beck A. (2003), These Negotiations Are Run like a Bazaar, "Yediot Acharonot," August 29, Sabbath Supplement, p. 12.

Ben Porat Y. (1985), Kreisky: I Sent Letters to Peres and Jibril and I Extracted the Negotiations from the Mud, "Yediot Acharonot," May 21, p. 3.

Bergman R. (2003), The True Price of the Tannenbaum Deal, "Yediot Acharonot," October 24, Sabbath Supplement, pp. 4-5.

Eichner A. (2003), A New Obstacle on the Way to a Deal - The Murderer of the Haran Family, "Yediot Acharonot," November 9, p. 3.

Eichner A. (2003), Now the Ball Is in Hezbollah's Hands, "Yediot Acharonot," November 10.

Eichner A. (2003), Their Hard Hour, "Yediot Acharonot," November 10, p. 2.

Glickman A. (2003), Sheikh Nasrallah Announced for the First Time: Tennenbaum Is Alive, "Yediot Acharonot," January 7, p. 17.

Haver A. (1983), The Soul-Searching We Have to Do: Is the Principle not to Submit to Extortion of Terrorists Broken, "Yediot Acharonot," November 27.

Haver A. (1985), The Decision on the Exchange Price Was Made Unanimously in the Government, "Yediot Acharonot," May 21, p. 6.

Limor Y. (2011), From Gaza to Mizpeh Hila in Five Years, "Yisrael HaYom," October 14, pp. 13-14. 
News Agencies (1983), Jibril Received Two Captives since There Wasn't Space in the Vehicle They Travelled in, "Yediot Acharonot," March 4, p. 1.

Perry S. (2000), Hezbollah Is Willing for U.N. Mediation, "Yediot Acharonot," October 11, p. 11.

Perry S. (2003), The Exchange Deal Does Not Include Arad, "Yediot Acharonot," August 27, p. 5.

Shavit A. (1985), Rabin Did Not Want the Elimination of Our Captives to Be on My Conscience, "Yediot Acharonot," May 24, Sabbath Supplement, p. 3.

Shavit A. (2011), Victory of Israeli Solidarity, "Haaretz," November 12.

Shibi H. (2000), Mofaz: There is Negotiation for the Release of the Abductees but the End Is Far off, "Yediot Acharonot," December 13, p. 15.

Shifer S. (2000), The Goal: To Release the Kidnapped Soldiers. The Way: Attack or Negotiations, "Yediot Acharonot," October 8, pp. 2-3.

Shifer S. (2003), Bring Tannenbaum back Alive, "Yediot Acharonot," October 3, Sabbath Supplement, p. 2.

Yarkoni Y. (2004), Four Lebanese with Blood on Their Hands Will Be Released, "Yediot Acharonot," January 27, p. 5.

Yechezkeli Z. (2004), The Terrorists Went Wild in the Air Force Plane, "Yediot Acharonot," January 30 , p. 2.

\section{Internet Websites (Hebrew)}

Buchbot A. (2012), To Remove the Issue of the Captives from the Prime Minister, January 5, http:// news.walla.co.il/item/1891423.

Prime Minister's Office (2011), Netanyahu's Speech at the Opening of the Special Meeting for the Confirmation of the Shalit Deal, October 11, http://www.pmo.gov.il/PMO/Communication/ Spokesman/2011/10/spokestart111011.htm.

\section{Negocjacje z organizacjami terrorystycznymi w celu uwolnienia uprowadzonych: między deklaracjami a praktyką. Przypadek Izraela}

\section{Streszczenie}

W ciagu ostatnich dekad kraje demokratyczne padały ofiarą ataków terrorystycznych przeprowadzanych w celu nawiązania negocjacji, co jest preferowanym sposobem działania niektórych organizacji terrorystycznych. W jakim stopniu demokratyczne rządy mogą skutecznie zwalczać tę odrażającą praktykę, zachowując swój liberalny czy demokratyczny charakter? Przypadki te stały się także jednym z najbardziej skomplikowanych dylematów zarówno w polityce wewnętrznej, jak i zagranicznej. Przeważa opinia, że nie można uniknąć spełnienia niektórych żądań terrorystów. Rząd może nawet zgodzić się na zapłacenie wysokiej ceny, aby wcześniej zakończyć sytuację. Na wysokość tej ceny mają wpływ media, ponieważ szerokie relacje ataków terrorystycznych przynoszą korzyści terrorystom, a tym samym zwiększają ich siłę przetargową. W przeciwieństwie do deklaracji przywódców izraelskich odnośnie negocjacji w przypadkach uprowadzenia, Izrael przyjął bardzo elastyczne podejście i nie jest zainteresowany przyjęciem sztywnej postawy polegającej na odmowie negocjacji. Stanowisko oponentów negocjacji z organizacjami terrorystycznymi jest takie, że negocjacje takie legitymizują te organizacje i przeprowadzane przez nie ataki terrorystyczne, tym samym osłabiając twierdzenie, że terroryzm nie jest uzasadnionym środkiem do osiagnięcia własnych celów i uniemożliwia użycie siły. Po przeanalizowaniu wszystkich transakcji wymiany więźniów przez państwo Izrael, okazuje się, że około 7500 terrorystów, w tym terrorystów mających krew na rękach, zostało uwolnionych w ramach różnych transakcji w zamian za 14 żywych żołnierzy i cywilów oraz 6 ciał żołnierzy. W samej tylko transakcji Shalit uwolniono 1027 terrorystów.

Słowa kluczowe: negocjacje z organizacjami terrorystycznymi, walka z terroryzmem, bezpieczeństwo narodowe, demokracja, media, Gilad Shalit 